Tohoku J. exp. Med., 1983, 139, 293-298

\title{
The Effect of Acute Inflammation on Iron Metabolism in Rats
}

\author{
Tatsumi Uchida, Tadayuki Igarashi, Teruo Suzuki, \\ Keiji Kokubun, Shin Matsuda and Shigeo Kariyone \\ The First Department of Internal Medicine, Fukushima \\ Medical College, Fukushima 960
}

Uchida, T., Igarashi, T., Suzuki, T., Kokubun, K., Matsuda, S. and Kariyone, S. The Effect of Acute Inflammation on Iron Metabolism in Rats. Tohoku J. exp. Med., 1983, 139 (3), 293-298 — Iron metabolism in rats with acute turpentine-induced inflammation was evaluated. In acute inflammation, reduced plasma iron and total iron-binding capacity values, shortened plasma iron disappearance time and lower plasma iron turnover were observed. The administration of ${ }^{59} \mathrm{Fe}$ chondroitin ferrous sulfate in order to evaluate the reticuloendothelial (RE) function revealed a significantly increased ${ }^{59} \mathrm{Fe}$ retention in the liver and lower incorporation into red blood cells. Radioactivity in hepatic RE cells was higher in acute inflammation than in control. These results suggest the possibility of a block in the transfer of iron from RE cells to the plasma iron pool during acute inflammation. - iron metabolism; turpentine-induced inflammation; reticuloendothelial cells; ${ }^{59} \mathrm{Fe}$ chondroitin ferrous sulfate

Anemia develops during chronic infections, which usually is normocytic and normochromic (Wintrobe 1981). The serum iron is characteristically decreased, total iron-binding capacity (TIBC) is reduced, and serum ferritin values are usually increased but sometimes normal (Wintrobe 1981). Ferrokinetic studies in patients with chronic infections indicate that erythropoiesis is normal or increased to only a moderate degree (Cartwright 1966). On the other hand, normal or increased marrow reticuloendothelial (RE) iron and the impairment iron release from the RE system may be suggested (Cartwright 1966). In this paper, abnormal iron metabolism and it's mechanism are presented in rats with inflammation induced by intramuscular injection of turpentine oil.

\section{Materials and Methods}

Experimental animals. Male rats of the Wistar strain, between 8 and 12 weeks of age, and weighing from 1.50 to $250 \mathrm{~g}$, were used in all experiments. Sterile inflammation was induced by the injection of $0.25 \mathrm{ml}$ of turpentine oil into the muscle of one thigh during ether anesthesia.

$R E$ and parenchymal iron labeling method. Two kinds of radioactive substances were employed for labeling hepatic RE and parenchymal cells (Cook 1972; Hershko 1973).

Received for publication, May 31, 1982. 
Radioiron labeling of hepatic RE cells was performed by injecting ${ }^{59} \mathrm{Fe}$ chondroitin ferrous sulfate ( ${ }^{59} \mathrm{Fe}-$ Blutal, RE tag, SA $30.7 \mathrm{mCi}$ per $\mathrm{mg} \mathrm{Fe}, 3.3 \mu \mathrm{g}$ Fe per ml, Dainabot Radioisotope Laboratory, Suita, Osaka) i.v. in a dose of $100 \mu \mathrm{g}$ of elemental iron.

Determination of serum iron, TIBC and ferritin level. Blood removed by exsanguination under ether anesthesia was centrifuged at $1,000 \times \mathrm{g}$ for $20 \mathrm{~min}$. The iron content and TIBC of the supernatant serum was measured by the method of International Committee for Standardization in Hematology $(1978 \mathrm{a}, \mathrm{b})$. Serum ferritin concentration and ferritin content in hepatic ferritin fraction were measured by the two sites radioimmunometric assay using antibody coupled paper discs as a solid phase (Niitsu et al. 1975).

Ferrokinetics in rats. Ferrokinetics in turpentine-induced inflamed rats were investigated. Radioactive iron $\left(1 \mu \mathrm{Ci}\right.$ of ${ }^{59} \mathrm{FeCl}_{3}$ dissolved in $0.5 \mathrm{ml}$ saline) was injected intravenously. Samples of tail vein blood were obtained 5, 15, 30, 60 and $120 \mathrm{~min}$ after the injection with $50 \mu \mathrm{l}$ disposable pipettes. Each sample was immediately transferred to a counting tube and radioactivity was determined in a well-type gamma spectrometer. Half-time clearance of ${ }^{59} \mathrm{Fe}$ was determined by least squared regression analysis. The blood volume was estimated from the factor $5.75 \mathrm{ml}$ per $100 \mathrm{~g}$ of body weight (Belcher and Harris 1957). Serum iron levels were determined by sacrificing the animals just after the study. Plasma iron turnover (PIT) was calculated as described by Cook et al. (1970) and was expressed as mg Fe per $\mathrm{kg}$ per day.

Iron release from the $R E$ cells in turpentine-induced inflammation rats. Iron release from the RE cells was determined after the injection of $1 \mu \mathrm{Ci}$ of ${ }^{59} \mathrm{Fe}$ chondroitin ferrous sulfate in control, turpentine-induced inflammation and transfused rats. The transfused rats were prepared by the intravenous injection of $1 \mathrm{ml}$ whole blood for 4 days. Samples of tail vein blood were withdrawn $1 \mathrm{hr}$ after the injection and then daily for the next 8 days. The radioactivity of each sample was plotted as the percent of counts per min to the radioactivity injected.

Measurement of tissue radioiron. In this series of experiments, RE tag was performed in control, turpentine-induced inflammation and $\mathrm{RE}$ overloaded rats. Inflamed rats were made by the intramuscular injection of $0.25 \mathrm{ml}$ turpentine oil for 4 days. RE overload was prepared by the injection of $3 \mathrm{mg}$ unlabeled chondroitin ferrous sulfate followed by ${ }^{59} \mathrm{Fe}$ chondroitin sulfate administration. The animals were sacrificed $1,3,7$ and 10 days after the injection of ${ }^{59} \mathrm{Fe}$-tagged compounds. Radioactivity and iron content of the total liver, ferritin and hemosiderin fraction were measured as follows: Liver uptake was determined from the activity in weighed aliquots of tissue related to total organ weight. Ferritin and hemosiderin fraction was separated by the method of Linder and Munoro (1972), in which liver was homogenized in 9 volumes of saline and this homogenate was heated at $70^{\circ} \mathrm{C}$ for $10 \mathrm{~min}$, followed by cooling and centrifugation. Sediment was kept as hemosiderin-rich fraction and supernatant as ferritin fraction for the counting of the radioactivity. Iron content of liver homogenate, ferritin and hemosiderin fraction was measured by the method of Barry and Sherlock (1971). Ferritin contents in hepatic ferritin fraction were measured by the two sites radioimmunometric assay.

Separation of hepatic RE cells. Suspensions of hepatic RE cells were prepared by a modification of the method of Cook et al. (1972), in which hepatic parenchymal cells are selectively destroyed by the proteolytic enzyme, pronase (Kaken-Kagaku Ltd., Tokyo). The liver, cut into 2 to $5 \mathrm{~mm}$ particles, was suspended in $35 \mathrm{ml}$ pronase solution, freshly prepared by dissolving $250 \mathrm{mg}$ pronase in $100 \mathrm{ml}$ balanced salt solution (BSS). This suspension was shaken in a water bath at $37^{\circ} \mathrm{C}$ for $30 \mathrm{~min}$ and the supernatant collected. After the sedimentation at $200 \times \mathrm{g}$ for $10 \mathrm{~min}$, the sediment was resuspended in $20 \mathrm{ml}$ BSS, followed by the centrifugation at $100 \times \mathrm{g}$ for $5 \mathrm{~min}$. The most of erythrocytes and Kupffer cells were sedimented and the residual erythrocytes were lysed by exposure to distilled water for 25 sec. Final centrifugation was performed at $200 \times \mathrm{g}$ for $5 \mathrm{~min}$ and hepatic RE cells were dried in air. The radioactivity was counted and expressed cpm per $\mathrm{mg}$ weight of $\mathrm{RE}$ cells. 
Statistical analyses of data. Values are given in terms of mean \pm s.E. Differences between mean values were analyzed by Student's $t$ test and taken to be significant when $p$ values were less than 0.05 .

\section{Results}

Serum iron, TIBC, ferritin concentration and ferrokinetic indices in control and turpentine-induced inflammation rats are shown in Table 1. A low serum iron and TIBC, shortened PID $\mathrm{T}^{1} / 2$ and low PIT were evident $(p<0.01)$. Serum ferritin concentrations were higher in inflamed rats than in control, but there was no significant difference.

Iron release from the RE cells in turpentine-induced inflammation rats was evaluated by ${ }^{59} \mathrm{Fe}$ red blood cell incorporation after the injection of ${ }^{59} \mathrm{Fe}$ chondroitin ferrous sulfate. There were no significant differences of ${ }^{59} \mathrm{Fe}$ red blood cell incorporation in control, inflammation (intramuscular injection of $0.25 \mathrm{ml}$ turpentine oil) and blood transfusion groups (Fig. 1).

In other experiments, inflamed rats (four times injections of turpentine-oil 0.25 $\mathrm{ml}$ each) and RE iron overloaded rats (injection of unlabeled chondroitin ferrous sulfate $3 \mathrm{mg}$ ) were uesd. ${ }^{59} \mathrm{Fe}$ incorporation in red blood cells influenced by

TABLE 1. Effect of inflammation on the iron metabolism

$\begin{array}{lcc} & \text { Control } & \text { Inflammation } \\ \text { Serum iron }(\mu \mathrm{g} / 100 \mathrm{ml}) & 225 \pm 12 & 52 \pm 8^{*} \\ \text { TIBC }(\mu \mathrm{g} / 100 \mathrm{ml}) & 300 \pm 20 & 148 \pm 14^{*} \\ \text { Ferritin }(\mathrm{ng} / \mathrm{ml}) & 83 \pm 19 & 114 \pm 41 \dagger \\ \text { PID T1/2 (min) } & 195 \pm 40 & 120 \pm 14^{*} \\ \text { PIT }(\mathrm{mg} / \mathrm{kg} / \text { day) } & 0.57 \pm 0.08 & 0.16 \pm 0.01^{*}\end{array}$

$n=4$. Mean \pm s.E. $* p<0.01, \dagger$ Not significant.

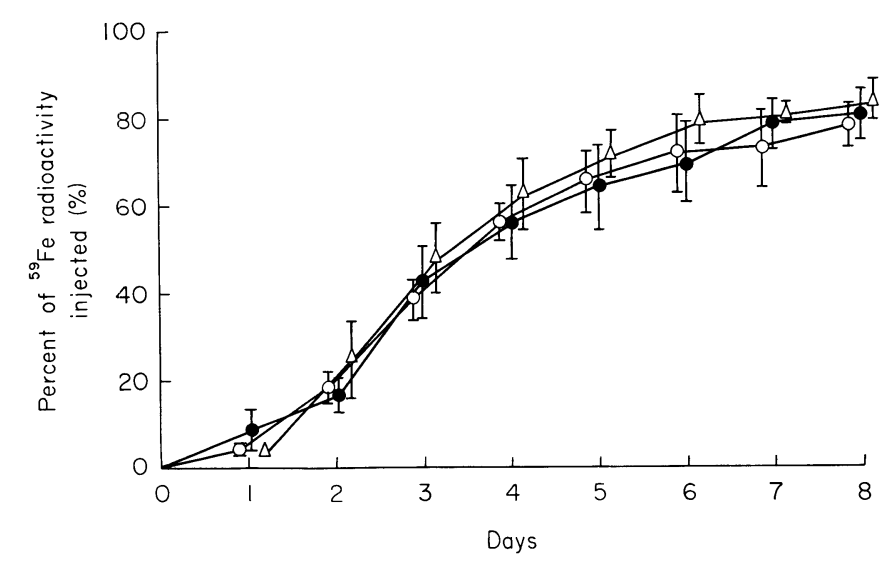

Fig. 1. ${ }^{59} \mathrm{Fe}$ red blood cell incoporation after the administration of radioactive chondroitin ferrous sulfate in turpentine-induced inflammation and transfused rats. There were no significant differences of ${ }^{59} \mathrm{Fe}$ incorporation between them. $\bigcirc-\circ$, transfusion; $\Delta-\Delta$, inflammation; $\bullet-\bullet$, control. 
the release of iron from $\mathrm{RE}$ cells was depressed in turpentine-induced inflammation and RE iron overloaded rats (Fig 2). Total liver radioactivity decreased slowly in the inflammation and RE iron overload corresponding with the lower red blood cell utilization. The ratio of ferritin to hemosiderin fraction in ${ }^{59} \mathrm{Fe}$ activity and in iron content is shown in Fig. 3. The ratio of hemosiderin fraction to total liver was constant in normal and inflammation, but tended to be higher in RE overload. The same phenomena were observed in total liver iron and hemosiderin iron content.
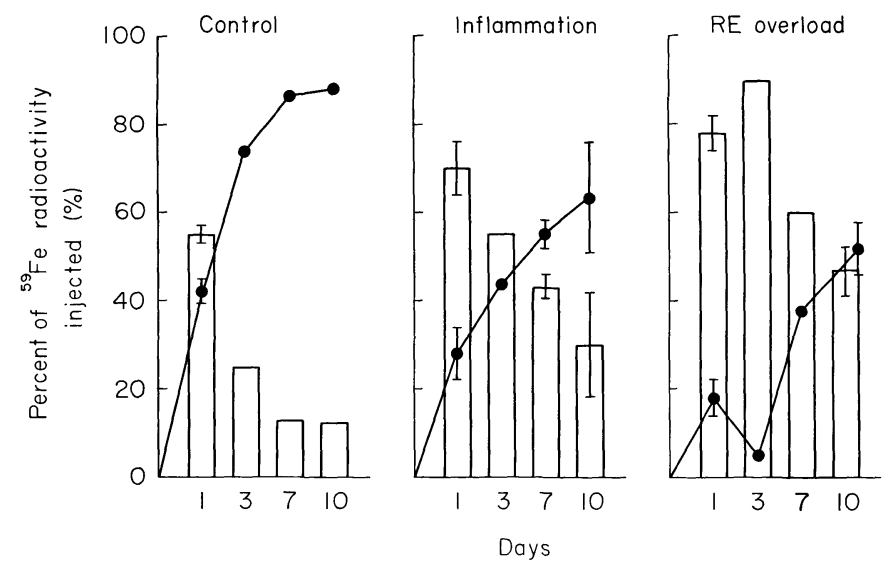

Fig. 2. The ratioactivity of total liver (column) and of red blood cells (solid line) after the injection of ${ }^{59} \mathrm{Fe}$ chondroitin ferrous sulfate (RE tag) in acute inflammation and RE iron overload. Total liver radioactivity decreased slowly both in inflammation and in $\mathrm{RE}$ overload corresponding with the lower red blood cell utilization.
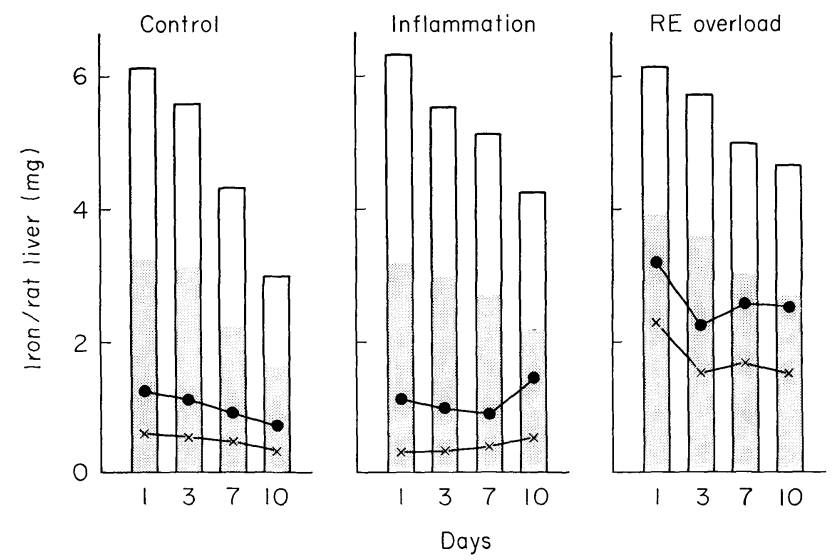

Fig. 3. The radioactivity of hemosiderin (shaded area) and ferritin fraction (unshaded area) after the injection of ${ }^{59} \mathrm{Fe}$ chondrotin ferrous sulfate. The ratio of hemosiderin fraction to total liver was constant in normal and inflammation, but tended to be heigher in RE overload. The same phenomena were observed in total liver iron (•) and hemosiderin iron content $(x)$. 


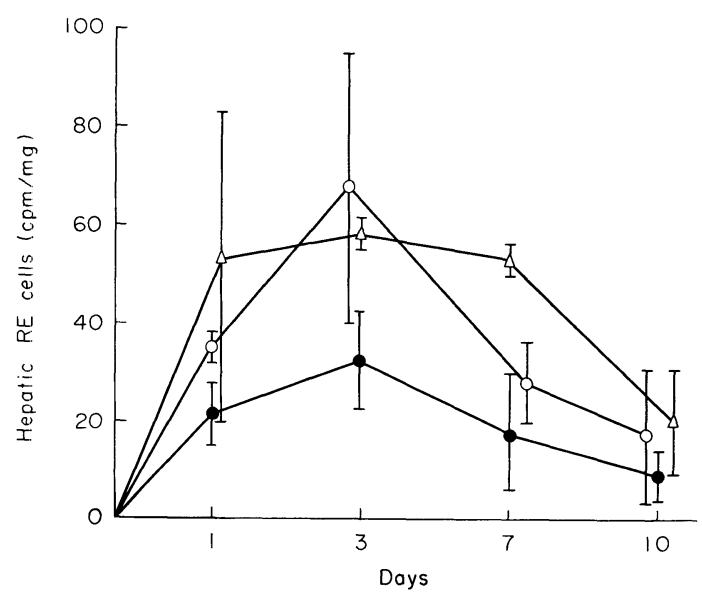

Fig. 4. The ratioactivity of hepatic RE cells after the injection of ${ }^{59} \mathrm{Fe}$ chondroitin ferrous sulfate. The radioactivity per $\mathrm{mg}$ of hepatic $\mathrm{RE}$ cells was higher in $\mathrm{RE}$ iron overload and turpentine-induced inflammation rats than in control. $0-0$, chondroitin sulfate; $\Delta-\Delta$, inflammation; $\bullet-\bullet$, control.

The radioactivity of hepatic $\mathrm{RE}$ cells after the injection of ${ }^{59} \mathrm{Fe}$ chondroitin ferrous sulfate is shown in Fig. 4. The radioactivity per mg of hepatic RE cells was higher in RE iron overload and turpentine-induced inflammation rats than in control, which suggests that restricted iron supply in inflammation is due to a block in iron release from $\mathrm{RE}$ cells.

\section{Discussion}

The pattern of alteration of iron metabolism in inflammation consists of hypoferremia, a decrease in transferrin, reduced transferrin saturation and normal or increased marrow RE iron (Cartwright 1966; O'Shea et al. 1973). Reutilization of iron from destroyed red cells is impaired due to retention of iron in RE cells (Freireich et al. 1957; Haurani et al. 1965). The average half time of plasma ${ }^{59} \mathrm{Fe}$ disappearance in the inflammation was $120 \mathrm{~min}$ as compared with 195 min in the control. The average PIT was $0.57 \mathrm{mg} / \mathrm{kg} /$ day as compared with 0.16 $\mathrm{mg} / \mathrm{kg} /$ day of control. It is apparent that there is marked inhibition of erythropoiesis in turpentine-induced inflammation rats (Bush et al. 1956; Zucker et al. 1974).

When ${ }^{59} \mathrm{Fe}$ labeled chondroitin ferrous sulfate was used, a significantly increased retention of radioactivity was observed in the liver during inflammation, which was found to be pronounced in hepatic RE cells by the selective separation of RE cells. ${ }^{59} \mathrm{Fe}$ incorporation to red blood cells was lower in inflammation than in control group. Fillet et al. (1974) reported the same results using a ${ }^{59} \mathrm{Fe}$ labeled heat denaturated red blood cells. These findings support the possibility of a block in the transfer of iron from hepatic RE cells to the plasma iron pool during acute inflammation. 


\section{References}

1) Barry, M. \& Sherlock, S. (1971) Measurement of liver iron concentration in needle biopsy specimens. Lancet, 1, 100-103.

2) Belcher, E.H. \& Harris, E.B. (1957) Studies of plasma volume, red cell volume and total blood volume in young growing rats. J. Physiol., 139, 64-78.

3) Bush, J.A., Ashenbrucker, H., Cartwright, G.E. \& Wintrobe, M.M. (1956) The anemia of infection. XX. The kinetics of iron metabolism in the anemia associated with chronic infection. J. clin. Invest., 35, 89-97.

4) Cartwright, G.E. (1966) The anemia of chronic disorders. Semin. Hematol., 3, 351375.

5) Cook, J.D., Marsaglia, G., Esbach, J.W., Funk, D.D. \& Finch, C.A. (1970) Ferrokinetics: a biologic model for plasma iron exchange in man. J. clin. Invest., 49, 197-205.

6) Cook, J.D., Hershko, C. \& Finch, C.A. (1972) Storage iron kinetics. I. Measurement of the cellular distribution of ${ }^{59} \mathrm{Fe}$ in rat liver. J. Lab. clin. Med., 80, 613-623.

7) Fillet, G., Cook, J.D. \& Finch, C.A. (1974) Storage iron kinetics. VII. A biologic model reticuloendothelial iron transport. J. clin. Invest., 53, 1527-1533.

8) Freireich, E.J., Miller, A., Emerson, C.P. \& Ross, J.F. (1957) The effect of inflammation on the utilization of erythrocyte and transferrin bound radioiron for red cell production. Blood, 12, 972-983.

9) Haurani, F.I., Burke, W. \& Martinez, E.J. (1964) Defective reutilization of iron in the anemia of inflammation. J. Lab. clin. Med., 65, 560-570.

10) Hershko, C., Cook, J.D. \& Finch, C.A. (1973) Storage iron kinetics. II. The uptake of hemoglobin iron by hepatic parenchymal cells. J. Lab. clin. Med., 80, 624-634.

11) International Committee for Standardization in Hematology (1978a) Recommendation for measurement of serum iron in human blood. Brit. J. Haematol., 38, 291-294.

12) International Committee for Standardization in Hematology (1978b) The measurement of total and unsaturated iron-binding capactity in serum. Brit. J. Haematol., 39, 281-287.

13) Linder, M.C. \& Munoro, H.N. (1972) Assay of tissue ferritin. Ann. Biochem., 48, 266278.

14) Niitsu, Y., Kohgo, Y., Yokoda, M. \& Urushizaki, I. (1975) Radioimmunoassay of serum ferritin in patients with malignancy. Ann. N.Y. Acad. Sci., 259, 450-452.

15) O'Shea, M.J., Kershenobich, D. \& Tavill, A.S. (1973) Effects of inflammation on iron and transferrin metabolism. Brit. J. Haematol., 25, 707-714.

16) Wintrobe, M.M. (1981) The anemia of chronic disorders. In: Clinical Hematology. 8th ed, Lea \& Febiger, New York, pp. 646-653.

17) Zucker, S., Friedman, S. \& Lysik, R.M. (1974) Bone marrow erythropoiesis in the anemia of infection, inflammation and malignancy. J. clin. Invest., 53, 1132-1138. 